\title{
A NON-INVASIVE METHOD FOR THE EXAMINATION OF MUSCLE GEOMETRY TO THE EXPLORATION OF THE CONTEXT OF \\ THE MUSCLE ACTIVITIES AND MUSCLE LENGTH CHANGES
}

\author{
Péter Katona ${ }^{1}$, Tamás Pilissy², Gábor Fazekas ${ }^{3}$, András Klauber ${ }^{3}$, József Laczkó ${ }^{1,2}$ \\ ${ }^{1}$ Semmelweis University Faculty of Physical Education and Sport Sciences, Budapest \\ ${ }^{2}$ Pázmány Péter Catholic University Faculty of Information Technology, Budapest \\ ${ }^{3}$ National Institute for Medical Rehabilitation, Budapest \\ solg@freemail.hu
}

\section{Introduction}

We use functional electric stimulation (FES) in the treatment of spinal cord injured patients since 2005, in pursuance of this we use a stimulator and electrodes to make the paralyzed muscles of the lower limb drive the pedal of a stationary bicycle ${ }^{1,2,3}$. The stimulation pattern for this device is developed by studying muscle activity patterns of healthy subjects. The healthy muscle geometry can only be measured with expensive diagnostic devices/methods (MR, CT). Our aim is to develop a method, based on kinematic data (coordinates of ultrasonic markers) accessible by movement analyzing systems and it describes mathematically the changes of the muscle geometry during movements, in our case during cycling lower limb movement. We discern relations of geometrical changes and muscle activities.

\section{Methods}

First, 3D coordinates of the markers, placed on anatomical landmarks of the left lower limb (Figure 1.) were measured. The measurement device was an ultrasonic movement analyzing system (CMS 70P, Zebris, Isny, Germany) that locates the place of ultrasonic speakers using three ultrasound sensitive microphones. This system applied a 3D coordinate system: the $\mathrm{X}$-axis is horizontal in the frontal plane directed medial to lateral, $\mathrm{Y}$-axis is horizontal

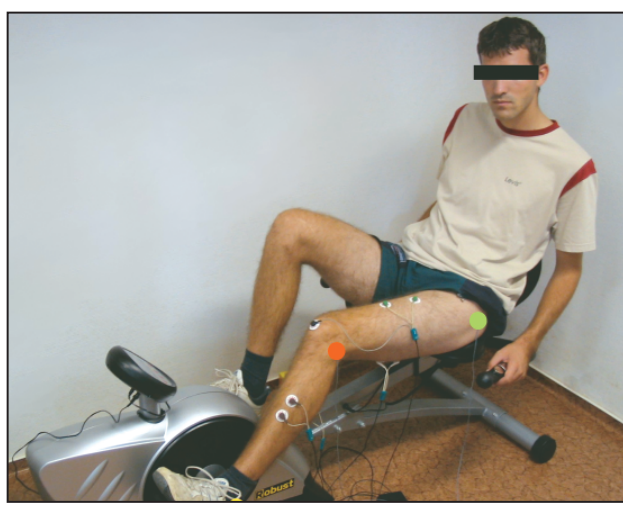

Figure 1. A subject during the measurement (the colored points show the places where the markers were placed)

in the sagittal plane directed forward, and $\mathrm{z}$ is perpendicular to the $x-y$ plane directed upward. This system has widely been used in studying multijoint movements ${ }^{4,5,6}$. Kinematic data (marker coordinates) were assessed with sampling frequency of $50 \mathrm{~Hz}$.

Then intrinsic local coordinate systems were defined (one in the ankle and one in the knee), the origo of these coordinate systems were placed into the suitable rotation center.

To localize the rotational center in the knee, the coordinates of the marker placed on the lateral epycondyle were translated along the $\mathrm{X}$ direction with half of the distance of the lateral and medial epycondyles. In the ankle the coordinates of the rotational center was com- 
puted from the coordinates of the marker placed on the lateral malleolus by translating it with $30 \mathrm{~m}$ along the $\mathrm{X}$ direction. This distance was a theoretical approximation of half of the distance of the lateral and medial malleoli.

The hip rotational center was localized translating the coordinates of the marker placed on the greater trochanter along the $\mathrm{X}$ axis with $60 \mathrm{~mm}$. This distance was a theoretical approximation.

Three axes were defined in the knee (the orig is in the rotational center): the $\mathrm{Y}$-axis was pointed to the rotational center of the hip, the $\mathrm{X}$-axis was pointed to the lateral epycondyle (where the marker was placed), the $\mathrm{Z}$-axis is the cross product of the $\mathrm{Y}$ - and $\mathrm{X}$-axes. Then three axes were defined in the ankle: the $\mathrm{Y}$-axis was pointed to the rotational center of the knee, the $\mathrm{X}$-axis was pointed to the lateral malleolus (where the marker was placed), the $\mathrm{Z}$-axis is the cross product of the $\mathrm{Y}$ - and $\mathrm{X}$ axes.

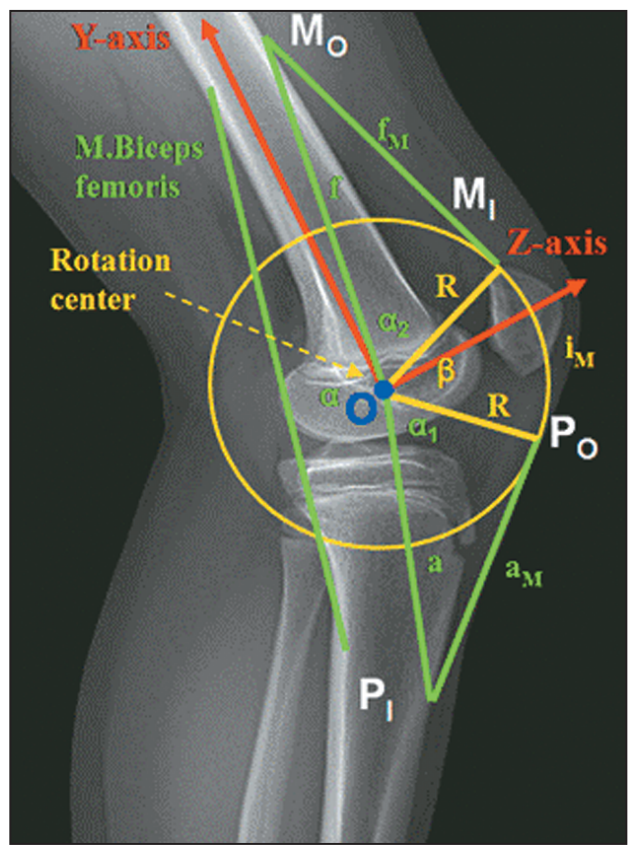

The spatial coordinates of the attachment points of the muscles were determined in these coordinate systems as function of time. Data from literature ${ }^{7,8}$ were used to compute the location of muscle attachments. The muscle length and its speed of change can be computed by trigonometric equations during the whole time of the movement. The algorithm was applied on 41 healthy subjects. The length and its change as a function of time of the subjects' Quadriceps and Biceps femoris were calculated using the received data during the movement (Figure 2 and 3, Equation 1 and 2).

$M_{l}=a_{M}+f_{M}+i_{M}$

$a_{M}=\sqrt{a^{2}-R^{2}}$

$f_{M}=\sqrt{f^{2}-R^{2}}$

$i_{M}=R \cdot \beta$

$\beta=2 \Pi-\left(\alpha+\alpha_{1}+\alpha_{2}\right)$

$\alpha_{1}=\arccos \left(\frac{R}{a}\right)$

$\alpha_{2}=a \cos \left(\frac{R}{f}\right)$

Figure 2. The schematic 3D figure of the algorithm used for the computation of the length of the Quadriceps

Figure 3. Two of the axes defined in the intrinsic coordinate system of the knee, the third one $(Z)$ is visible on figure 2 .

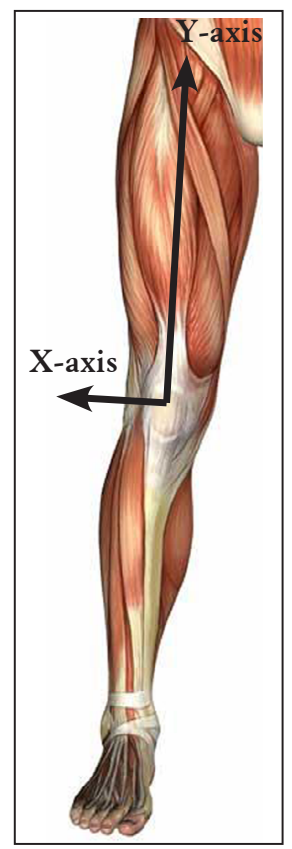


Where $M_{l}$ is the muscle length, $i_{M}$ is the section of the muscle that belong to the patella, $f_{M}$ is the section of the muscle from its origin to the patella, $a_{M}$ is the section of the muscle from its insertion to the patella (patella ligament), $a$ is the distance between the rotation center (O) and the insertion of the patella ligament $\left(\mathrm{P}_{\mathrm{I}}\right), f$ is the distance between the rotation center and the origin of the muscle $\mathrm{M}_{\mathrm{O}}, R$ is the radius of the knee, $\mathrm{P}_{\mathrm{I}}$ is the insertion and $\mathrm{P}_{\mathrm{O}}$ is the origin of the patella ligament, $\alpha$ is the knee angle (spanned by $a$ and $f$ ), $\alpha_{1}$ is the angle spanned by the vectors $\mathrm{OP}_{\mathrm{I}}$ and $\mathrm{OP}_{\mathrm{O}}, \alpha_{2}$ is the angle spanned by the vectors $\mathrm{OM}_{\mathrm{I}}\left(\mathrm{M}_{\mathrm{I}}\right.$ is the insertion of the muscle) and $\mathrm{OM}_{\mathrm{O}}, \beta$ is the angle belonging to the ark $\left(\mathrm{i}_{\mathrm{M}}\right)$, all angles were used in radian.

\section{Results}

It was observed in the case of the Quadriceps (Figure 4.), that the largest extension of the muscle (largest length) coincides with the largest electric activity of the muscle (the maximum of the EMG curve), so the muscle activity is highest at the maximal length of the muscle.

In the case of the Biceps femoris the highest electric activity can be observed during the extension of the muscle (Figure 5.). From our data, it is obvious that the maximum length of one of the observed muscle coincides with the minimal length of the other, antagonist muscle.

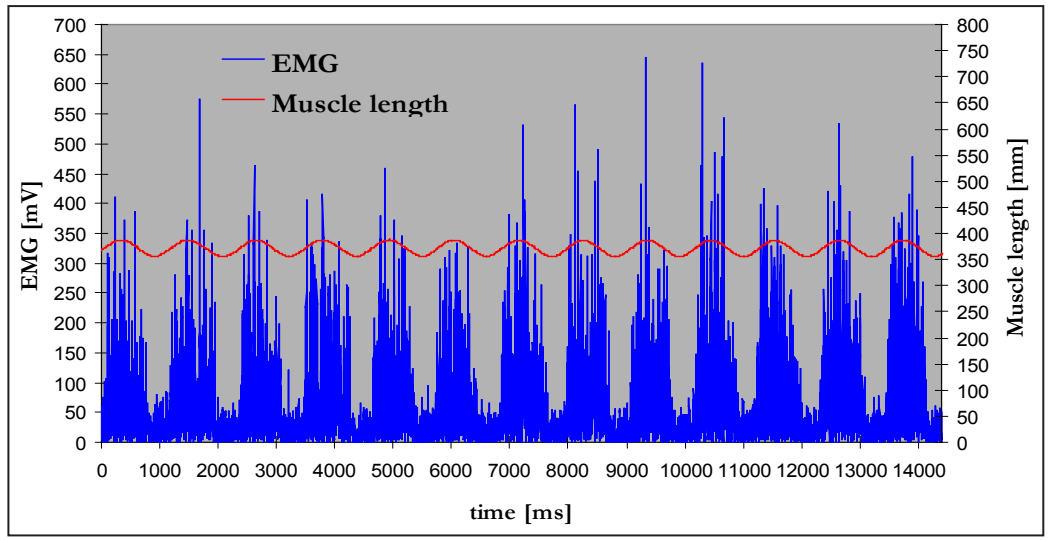

Figure 4.

The measured EMG and the computed muscle length data of subject K01's left Quadriceps muscle during the cycling movement

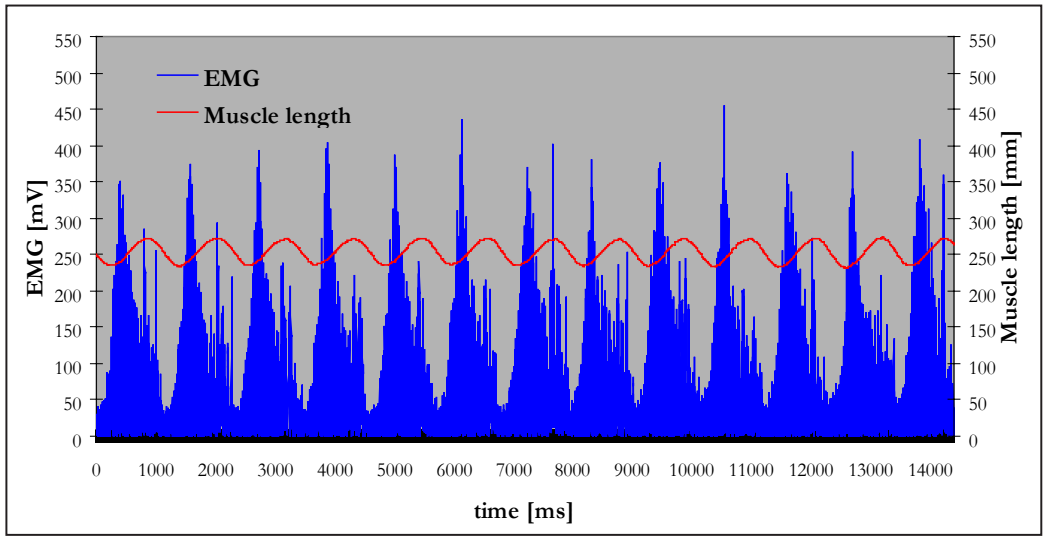

Figure 5.

The measured EMG and the computed muscle length data of subject K01's left Biceps femoris muscle during the cycling movement 


\section{Conclusion}

Observing the electric activity and length of Quadriceps, the following contexts were deduced:

- When the muscle shortened maximally the length of the muscle begins to extend through the effect of the antagonist muscles (or through other force, that is in terms of the examined muscle exterior strength)

- Due to the extension, and the regulation of the motion (to increase the stability) electric signs arrive into the muscle, this leads to the deceleration of its length change

- Under the maximum electric activity of the muscle (at the maximum of the EMG curve) the extension of the muscle stops, indeed the muscle begins to contract

- Decreasing electric activity was observed during the contraction, what can be explained with the muscle force of the other lower limb. For example the Quadriceps shortening not ensues only because of his own effort but the effort of the Biceps femoris of the other lower limb. Thus, it is not necessary to produce high electric activity (force) to maintain the motion, it is more necessary during the switch between stretching and shortening, when the contraction begins in the required muscle.

The electric activity of the Biceps femoris muscle shows that this muscle plays an important role in the regulation of the motion thereby, that its activity is maximal at the time when the velocity of the stretching grows, so its activity makes the knee not to bend but it sets back the extension of it $^{9,10}$.

\section{Discussion}

Anthropometric data of individual subjects are required to define appropriate electrical activity patterns and forces of muscles rotating particular joints. Muscle synergy depends on muscle geometry. Thus the quantitative analysis of changes in muscle length is essential to define stimulation patterns for functional electrical stimulation of people with paralysed limbs. The relation between joint rotations and muscle length is studied for healthy subjects ${ }^{11}$. Based on this approach we proposed spatio-temporal cooperation of knee flexor and extensor muscle.

With the calculated contexts, the stimulation pattern used in the FES treatment of the spinal cord injured patients is modifiable. The therapy becomes more efficient thereby, that an artificial pattern was provided, which is biologically inspired and it takes notice of individual anatomic data. There is an infinity of different combinations of muscle activities to perform a motor task as cycling. The proper coordination and regulation of such movements may depend on geometric properties and may be enhanced by studying muscle synergies using theoretical approaches even without expensive experiments ${ }^{12}$. However in our knowledge no detailed quantitative analysis of muscle coordination is given for cycling lower limb movements. Our presented method is a research tool for further development of artificially designed muscle activity patterns. The next step is to establish 3D muscle forces required to execute a planned movement of a limb with given muscle geometry. 


\section{REFERENCES}

1. Pilissy T, Klauber A, Fazekas G, Laczkó J, Szécsi J. (2008): Improving functional electrical stimulation driven cycling by proper synchronization of the muscles. Clinical Neuroscience/Ideggyógy Szle 61(5-6) pp. 162-167.

2. Szécsi J, Fincziczki Á, Laczkó J, Straube A. (2005): Elektrostimuláció segítségével meghajtott (háromkerekû) kerékpár: Neuroprotézis harántsérült páciensek mindennapos használatára. Rehabilitáció, 15. évfolyam pp. 9-14.

3. Laczkó J, Pilissy T, Klauber A. (2008): Modeling of Limb Movements for Controlling Functional Electrical Stimulation of Paraplegics. Proc. of the Third Hungarian Conference on Biomechanics. ISBN 978963064307 8. pp. 151-157.

4. Hermsdörfer J, Marquardt C, Wack S, Mai N. (1999) Comparative analysis of diadochokinetic movements. J Elektromyogr Kinesiol 9: 283-295.

5. Keresztényi Z, Cesari P, Fazekas G, Laczkó J. (2008): The relation of hand and arm configuration variances while tracking geometric figures in Parkinson's disease - "aspects for rehabilitation". International Journal of Rehabilitation Research 2009;32:53-63.

6. Kiss RM, Kocsis L, Knoll Zs. Joint kinematics and spatial temporal parameters of gait measured by an ultrasound based system. Medical Engineering\&Physics 2004; 26:611-620.
7. Brand RA, Crowninshield RD, Wittstock CE, Pedersen DR, Clark CR, van Krieken FM. (1982): A model of lower extremity muscular anatomy. Journal of Biomechanical Engineering, Vol. 104, pp. 304-310.

8. Hoy MG, Zajac FE, Gordon ME. (1990): A musculoskeletal model of the human lower extremity: the effect of muscle, tendon, and moment arm on the moment-angle relationship of musculotendon actuators at the hip, knee, and ankle. Journal of Biomechanics, Vol. 23, No. 2, pp. 157-169.

9. Katona P, Pilissy T, Fazekas G, Laczkó J. (2009): Ízületi szögsebességek, izomaktivitások és a pedálhajtás sebességének kapcsolata kerékpározó mozgáskor. VII. Országos Sporttudományi Kongresszus, In: Magyar Sporttudományi Szemle, 10. évf. 38. sz. p. 33.

10. Katona P. A Quadriceps és Hamstrings izmok elektromos aktivitásának vizsgálata kerékpározó mozgás során a sebesség függvényében, National Congress on Sport Sciences for Students 2009, (in Hungarian)

11. Hawkins D \& Hull ML. (1990): A method for determininglower extremity muscle-tendon lengths during flexion/extension movements. J Biomech 23:487-494.

12. Bernstein NA. (1967): The co-ordination and regulation of movements. Pergamon, Oxford

Supported by ETT 363/2006, Scientific Council of Healthcare

\section{Péter Katona}

Semmelweis University Faculty of Physical Education and Sport Sciences, Budapest H-1123 Budapest, Alkotás u. 44. 